\title{
The impacts of drought on freshwater ecosystems: an Australian perspective
}

\author{
Nicholas R. Bond · P. S. Lake $\cdot$ Angela H. Arthington
}

Received: 2 December 2007 / Revised: 29 January 2008/Accepted: 5 February 2008/Published online: 26 February 2008

(C) Springer Science+Business Media B.V. 2008

\begin{abstract}
Southeastern Australia is presently experiencing one of the worst droughts observed in the region in the last 200 years. The consequences of drought have been far reaching both for human consumptive uses and for aquatic ecosystems, and serve to highlight several important aspects of the nature of droughts, their ecological impacts, and how humans respond to them. Running water ecosystems are the dominant form of freshwater ecosystem in Australia, yet, despite the high frequency of drought we lack a basic understanding of the consequences of long-term droughts (as distinct from seasonal droughts) as an ecosystem disturbance, and more is known about drought effects on flowing than on standing waters. Drought is well defined and characterised meteorologically, but hydrologically its characterisation is equivocal. While drought severely impacts natural aquatic ecosystems, its effects have been and are exacerbated by direct and indirect anthropogenic modifications to streams and their catchments. In streams the major impacts are the loss of water and habitat availability, and the reduction, if not severing, of
\end{abstract}

Handling editor: K. Martens

N. R. Bond $(\bowtie) \cdot$ P. S. Lake

School of Biological Sciences, Monash University,

Clayton, VIC 3800, Australia

e-mail: Nick.Bond@sci.monash.edu.au

\section{A. H. Arthington}

Australian Rivers Institute, Griffith University, Brisbane, Australia connectivity (lateral, longitudinal and vertical). Despite the relative frequency of drought in Australia we have failed to develop long-term management strategies capable of contending with droughts and their impacts, particularly in catchments where human disturbances have reduced the natural resistance and resilience of aquatic ecosystems, and where the demand for consumptive water use is high and rising. Here, we provide a commentary on drought and its implications for the management of freshwater ecosystems. We begin with a general discussion of drought and its impacts on streams and rivers before discussing some of the more specific management issues and response strategies that have arisen in response to the current drought in Australia. Throughout we consider global as well as local examples. We conclude by highlighting important knowledge gaps and by providing some general principles for better incorporating droughts and their impacts into river management strategies.

Keywords Drought · Resilience ·

Refugia $\cdot$ Disturbance $\cdot$ Environmental flows

\section{Introduction}

Drought is a recurring theme in Australia, with the most recent event, the so called 'millennium' drought, now having lasted for almost a decade. This severe drought has affected most of southern and 
eastern Australia and is regarded as one of the worst in the region since European settlement (Murphy \& Timbal, 2007), with many rivers experiencing record low flows over this period-in some cases almost $40 \%$ below previous records (Murray-Darling Basin Commission, 2007). Both anecdotal observations and empirical data clearly indicate that the drought has had severe impacts on aquatic ecosystems. Populations of many aquatic taxa-from small invertebrates to fish-have declined in abundance and in some rivers undergone localised extinctions (e.g. Bond \& Lake, 2005b; Lind et al., 2006). Riparian zones have been depleted with an iconic species, the river red gum (Eucalyptus camaldulensis), dying over extensive areas (Murray-Darling Basin Commission, 2003; Victorian Environment Assessment Council, 2006). Other impacts, such as changes in aquatic populations and altered biogeochemical processes are becoming evident but remain poorly understood.

The response to this drought from scientists and managers has been both haphazard and uncoordinated. As the severity of the drought was realised, concern from both parties grew rapidly. Scientists seeking to document the impacts of the drought have been hampered by little existing research, limited dedicated funding and a lack of extensive pre-drought data in the worst affected areas. Managers under pressure from politicians and stakeholders have been making short-term decisions about water allocation among competing users, including environmental purposes, often in the absence of a clear understanding of the long-term consequences. With the frequency and severity of droughts forecast to increase with climate change in many parts of the globe, including the southern parts of Australia, the impacts of drought on aquatic ecosystems will likely increase over the coming decades (Commonwealth Scientific and Industrial Research Organisation \& Australian Bureau of Meteorology, 2007). Drought impacts, linked to other consequences of climate change (e.g. higher temperatures, less frequent floods) clearly need more attention from scientific and management perspectives.

Our goal in this article is to summarise current knowledge of the impacts of drought on aquatic ecosystems, and to discuss measures taken to mitigate and contend with drought-both from a scientific perspective and the viewpoint of river managers. Whilst there is an extensive body of literature on drought, surprisingly few studies are of a broad geographic extent and of the desirable multidisciplinary scope (Lake et al., 2007). Our focus is intentionally on Australia, but many of our main points and recommendations are more broadly relevant.

\section{What is drought?}

Drought can be divided into four different categories-meteorological, agricultural, hydrological and socio-economic. There is no universal definition of drought, but a working definition of meteorological drought is that it is "an extended period-a season, a year, or several years-of deficient rainfall relative to the statistical multi-year mean for a region" (Druyan, 1996b). Drought must be distinguished from aridity, in that regarding the above definition for drought, aridity occurs in a region where there is a high probability of rainfall below a low threshold (e.g. $<20 \mathrm{~cm}$ per year; Druyan, 1996a) for a long and possibly indeterminate time (Coughlan, 1985).

In Australia, the usual definition of drought is meteorological and is determined by the Rainfall Deciles method (Gibbs \& Maher, 1967), wherein a drought is detected when the observed 3-month total lies in the lowest $10 \%$ of the long-term precipitation record. In the USA, agricultural drought is determined by the Palmer Drought Severity Index and hydrological drought by the Palmer Hydrological Drought Index and other indices such as the Total Water Deficit Index (Keyantash \& Dracup, 2002). In Australia, as in many other parts of the world, there are no clearly adopted indices for agricultural drought and hydrological drought. This lack of a clear universal definition for hydrological drought makes attempts to compare the impacts of drought on freshwater ecosystems between places and between times quite difficult (Lake et al., 2007). Droughts are a normal component of the climate of Australia (McKernan, 2005). Most droughts in Australia, but not all, are linked to the El Niño phase of the El Niño/ Southern Oscillation phenomenon (Schiewer, 1998).

As a natural hazard, drought can cause immense economic and social damage, yet it remains poorly understood. Once a meteorological drought sets in both agricultural and hydrological drought may follow. Hydrological drought consists of two 
components-surface water drought and groundwater drought, with the latter lagging well behind surface water drought in both commencing and finishing. Drought is unusual as a natural hazard in that it is a disturbance of deficiency rather than excess. It has three major characteristics-intensity, duration and spatial extent. In terms of the latter, note that drought never occurs as a small scale short-term disturbance (Wilhite, 2000). In this context it is important to distinguish between dry periods that have been termed 'seasonal' droughts, which are frequent and predictable, from 'supra-seasonal' droughts, which are aberrant and unpredictable (Lake, 2003). It is the latter type that we concentrate on in this article.

As a drought develops, the normally expected precipitation fails to occur at the expected time (season). The failure of rainfall leads to a loss of soil moisture, surface runoff and groundwater recharge. In streams with seasonal drought, the biota appear to be well adapted to this predictable hazard, but if such systems are subject to supra-seasonal drought the biota may suffer losses if not local extinctions (Boulton, 2003; Magalhaes et al., 2007). In the early stages of supra-seasonal drought, temporary water bodies, be they standing water or flowing water, may dry up or become reduced to a series of diminishing pools. As drought builds, water levels and volumes in natural perennial waters drop. In flowing waters, a number of potential thresholds may be crossed. Initially drought may cause a contraction in the wetted area of streambed, isolating marginal habitats. This is followed by the critical threshold of cease-toflow after which streams become a series of pools that in severe drought may themselves disappear (Boulton, 2003; Lake, 2003). As drought depletes surface waters, it should be noted that groundwater levels and volumes may, with time, start to be reduced (Van Lanen \& Peters, 2000). Groundwater drought is poorly understood, but it is critical to recognise that groundwater often forms the base flow of surface systems and also that many wetland systems are groundwater-dependent. When normal rainfall returns, meteorological drought typically breaks well before surface water drought and a very long time before groundwater drought.

All of the above applies to drought as a natural phenomenon affecting natural terrestrial and aquatic ecosystems. Such a situation of purely natural droughts uninfluenced by human activities is probably now rare in much of settled Australia and many other parts of the world. There is considerable evidence that human activities across catchments and in water bodies have served to exacerbate the extent and impacts of drought. Major changes to land cover by human activities have changed runoff and groundwater dynamics (e.g. Van Dijk et al., 2006). With land clearance and grazing, catchment storage of water has diminished due to a reduction in percolation of surface water below ground, and an increase in flashy runoff events. Urbanisation, with increases in impervious surfaces, may also reduce catchment water storage and produce more flashy hydrographs and more frequent runoff events (Walsh et al., 2005). The building of dams and weirs typically severs longitudinal connectivity and creates large reservoirs with high volumes of water loss due to evaporation. In the absence of drought, water extraction may reduce flow volumes in running waters thereby increasing their susceptibility to the effects of drought. With drought, the increased demand for water may lead to high levels of water extraction, hastening the damaging impacts of drought. This may apply to large-scale irrigation as well as to numerous local and small extractions to meet stock and domestic demand-the death by a thousand sucks. All of these changes have served to exacerbate the impacts of natural drought and to delay ecological recovery from drought. While the effects of low flow and water extraction in drought-affected rivers can be offset partly by industrial and sewage wastewater discharges into the rivers, the hydrologic benefits may be compromised by declines in water quality (Andersen et al., 2004; Aravinthan, 2005). Rather bizarrely in some systems, such as the Murray River in southeastern Australia, in times of natural low flow or even drought, large volumes of water may be delivered to downstream irrigators, generating 'anti-droughts' (Boulton, 2003; McMahon \& Finlayson, 2003). We have a poor understanding of the ecological ramifications of 'antidrought' flows that tend to elevate low flows and create more stable hydraulic conditions than would normally occur during low flow periods.

\section{Impacts of drought}

Drought in standing water bodies occurs as surface runoff and stream inputs decline and, as droughts 
usually occur in times of high temperature, evaporation may increase sharply. As drought progresses, water levels recede from the normally highly productive littoral zone, stranding some of the fauna (e.g. mussels, snails) and flora, such as rooted aquatic macrophytes (e.g. Furey et al., 2006). High water temperatures that may be accompanied by stratification and increasing conductivity (salinity) may, along with decreasing oxygen levels, severely stress aquatic fauna. The combination of high temperatures and low oxygen levels may eliminate some fish species. With stratification and/or stagnant conditions, nutrients may build up increasing the risk of algal blooms during the drought, in particular blooms of toxic blue green and golden algae (e.g. Ha et al., 1999; Colley, 2004), which can cause extensive fish kills (Colley, 2004) and may be harmful to livestock and domestic animals (Davies, 1978; Briand et al., 2003; Vidal, 2006). In addition, initial flows associated with the breaking of a drought have been observed to spread outbreaks of some forms of toxic microalgae downstream (Brazos River Authority, 2002).

Drought impacts in flowing waters are better understood than those in standing waters. In streams and rivers, as water levels in the channel drop, there is a weakening of lateral connectivity as the water recedes from the riparian and littoral zones and from backwaters (Boulton, 2003). This can result in considerable habitat loss and a decrease in riparian inputs of organic matter, both living and detrital. The stream may then enter into an extended period of low flow. With less riparian shading and high air temperatures, high water temperatures can result in fish kills and the loss of macroinvertebrates (e.g. Tramer, 1977; Boulton \& Lake, 1992; Boulton et al., 1992; Velasco \& Millan, 1998). In pools, filamentous algae may proliferate, especially if there are high levels of nutrients in the groundwater (Dahm et al., 2003). Extended low flows can stress stream fish and lead to reduced growth and recruitment for some, but usually not all species in rivers and streams (e.g. Matthews \& Marsh-Matthews, 2003; Elliott, 2006).

In large floodplain rivers, drought prevents seasonal inundation of floodplain wetlands and can extend the duration of spells during which floodplains are not flooded. The lack of flooding for long durations (decades), caused by either drought or river regulation or by both together, greatly depletes the invertebrate egg bank on the floodplain, so that when floodplain inundation events do occur, the expected micro-invertebrate "boom" is greatly diminished (Jenkins \& Boulton, 2007). Aquatic biota living in billabongs (oxbow lakes and lagoons) decline due to low oxygen levels and high water temperaturesconditions that may result in fish kills. Even robust riparian trees, such as river red gum, can become stressed and die - a fate made more likely by the prolonged absence of flooding below large dams (Murray-Darling Basin Commission, 2003; Victorian Environment Assessment Council, 2006). Water quality may decline through increases in nutrients and salinity in the channels of large rivers and low water levels and lack of hydrological cues may inhibit recruitment of some fish species (Bunn \& Arthington, 2002).

As the drought continues, the critical threshold of cease-to-flow can occur (Boulton, 2003). As this occurs fish and invertebrates may move into pools, some of which may persist as refugia, whilst other pools may, in time, dry up, killing their inhabitants. Very noticeable with flow cessation is the decline in fauna strongly dependent on flowing water, such as riffle-dwelling insects (e.g. simuliid larvae, hydropsychid caddisflies) and other invertebrates such as mussels (e.g. Golladay et al., 2004). The spatial pattern of drying is dependent on water volumes, channel morphology and patterns of hydrological connectivity. Shallow stream sections such as riffles may dry rapidly, whilst deep pools, especially shaded ones, may persist throughout the drought (if they are not depleted by stock watering and/or waterhole pumping). Here again, human disturbances that reduce geomorphic complexity (e.g. sand slugs) can greatly reduce waterhole depth, volume and persistence (Bartley \& Rutherfurd, 2005).

Longitudinal fragmentation prevents the normal transport of nutrients, biota and organic matter down river channels, often creating different conditions in each pool, such that each may become a distinctive lentic environment (Lake, 2005). In some pools, especially unshaded ones, algal blooms may develop (Dahm et al., 2003). With time, conductivity may rise, high temperatures and stratification may occurall of which may severely stress the normal stream biota. In pools with quantities of stored organic matter (e.g. riparian leaves) the levels of dissolved organic matter (DOC), mostly in the form of polyphenols, may rise, and increased DOC concentrations 
combined with low oxygen levels may severely stress biota, especially fish (Gehrke et al., 1993; McMaster $\&$ Bond, in press). In Australia, riparian leaf-fall normally occurs in summer and when this input occurs during drought, high DOC levels in pools can be a significant hazard for aquatic species (McMaster \& Bond, in press).

A noticeable change that occurs in isolated riverine pools is the switch from a flowing water invertebrate fauna to one more typical of standing water bodies, such as farm dams. This fauna is highly mobile, well adapted to severe conditions and largely composed of airbreathing predators such as hemipterans (bugs) and coleopterans (beetles; Lake, 2003; Boulton \& Lake, 2008). Competition, both intra- and inter-specific, may arise in the confined habitat of these isolated pools and predation by fish and the lentic newcomers may become intense (Matthews \& Marsh-Matthews, 2003). The fauna of river pools and wetlands may also be depleted by terrestrial predators-birds in particular (Kushlan, 1976; Tramer, 1977). In pools with high densities of trapped fauna the levels of parasitism and disease, notably of fish, can rise (Medeiros \& Maltchik, 1999).

In summary, drought in both standing and flowing water systems can have major ecological effects, stressing and depleting both fauna and flora. Loss of habitat, poor water quality and biotic interactions, especially predation, all have a major effect on aquatic biota and ecosystem functioning (Boulton, 2003; Dahm et al., 2003; Lake, 2003; Matthews \& Marsh-Matthews, 2003; Stanley et al., 2004). Overall, the impacts of drought on population and community structure are better understood than impacts on ecosystem processes.

\section{Resistance, resilience, and recovery from drought}

The popular view of droughts in Australia, and one which has scientific support, is that they are a perturbation to which aquatic biota are well adapted (e.g. Humphries \& Baldwin, 2003). Yet such expectations do not logically lead to the conclusion that drought stricken ecosystems will rapidly recover. Droughts put aquatic biota under increasing stress as they represent progressive loss of aquatic habitat, depletion of food resources and decline of water quality, with an increased likelihood of biotic interactions as flow reduces. As a perturbation, droughts occur over large (landscape) spatial scales, so they potentially threaten the survival, not only of individual aquatic organisms, but also of regional populations, or even species themselves. Indeed, the present-day natural distributions of many native aquatic species have been strongly influenced by past natural climatic fluctuations including changing frequency, severity and duration of droughts (Matthews, 1998; Douglas et al., 2003).

Many native biota in drought prone systems possess adaptations which allow them to either survive the drought by 'sitting it out' (resistance traits) or to recolonise and recruit after the drought breaks (resilience traits). Species that 'sit it out' do so by either possessing desiccation resistant life-history stages or by making use of remnant habitats offering less harsh conditions in an otherwise drought-affected environment. Such habitats-termed 'refugia'-are critical to the survival of many species in drought prone rivers and wetlands (Magoulick \& Kobza, 2003), and act as source populations for subsequent recolonisation and population growth (Adams \& Warren, 2005; Arthington et al., 2005). Typically, species that recolonise have well-developed mechanisms allowing widespread and rapid dispersal among suitable habitat patches (e.g. many fish and waterbirds; Unmack, 2001; Kingsford \& Norman, 2002; Graham \& Harris, 2005; Poiani, 2007). Australian aquatic fauna and flora are characterised by the high prevalence of both resistance and resilience traits, reflecting the evolutionary significance of drought as a selective pressure on aquatic biota and ecosystems (Boulton, 2003; Brock et al., 2003).

It seems to be a popular community expectation that when droughts break aquatic biota and ecosystem processes will simply bounce back to their pre-drought condition. From a scientific perspective such an expectation appears to be unfounded as we lack the long-term studies required to fully investigate recovery processes (Lake et al., 2007). However, an emerging theme is the longer and more severe the drought, the longer that recovery will take, with long lags and possibly local species extinctions (Lake, 2006).

In addition to the natural changes to freshwater ecosystems brought about by drought, in modified catchments droughts now have the capacity to cause unprecedented and irreversible change to freshwater ecosystems. Activities such as the construction of 
reservoirs and water extraction have greatly disrupted the connectivity of river systems and patterns of flow such that many habitats have been extensively modified or isolated and many rivers have not received their natural flows for decades (Kingsford, 2000; Ball et al., 2001; Kingsford \& Thomas, 2004). Of particular concern is the impact of farm dams on streamflows in unregulated catchments (Van Dijk et al., 2006). Whilst much attention is currently focussed on large regulated rivers, the proliferation of farm dams in many upland catchments over the last decade- $37 \%$ increase in number and $48 \%$ volume in the Murray-Darling Basin (Van Dijk et al., 2006) has meant that small streams and wetlands have been deprived of what little runoff has occurred during the drought. Due to their small size and wide distribution, farm dams have received little attention from water managers, and remain unlicensed for stock and domestic purposes in many Australian jurisdictions. Yet hydrological modelling suggests that during drought years farm dams can capture most of the annual flow in low-rainfall catchments (McMurray, 2006). It is clear that for many small streams and rivers such reductions in flow are unsustainable.

In addition to reductions in flow, agricultural activities have reduced if not destroyed riparian vegetation and increased the input of nutrients and sediments in many catchments, causing marked declines in habitat and water quality (Ball et al., 2001; National Land and Water Resources Audit, 2002; Pusey \& Arthington, 2003). Introduced species (e.g. Carp Cyprinus carpio, Mosquitofish Gambusia holbrooki, tilapia Oreochromis mossambicus, water hyacinth Eichhornia crassipes and para grass Urochloa mutica) have also invaded and proliferated in many water bodies (Ball et al., 2001), although they too are affected to varying degrees by drought. All of these factors have imposed severe stresses on aquatic ecosystems, such that many species have much reduced and fragmented distributions and are consequently more vulnerable to extinction (Ball et al., 2001; National Land and Water Resources Audit, 2002). It is thus critical to recognise that the natural capacity (both resistance and resilience) of aquatic ecosystems to cope with drought has been lost or much reduced in many regions, but particularly in those impacted by intensive land use, loss of riparian vegetation, barriers to movement and altered flow regime.

\section{A commentary on management response to the current drought in southeastern Australia}

The potential impacts of drought on the security of human water demands have long been recognised in Australia, giving rise to the highest levels of percapita water storage anywhere in the world (Australian Bureau of Statistics, 2007). These high levels of storage have, to a large degree, effectively buffered humans against low levels of runoff and high interannual variability in river discharge. Yet, in spite of such measures droughts have continued to inflict periodic stress on both human society and environmental systems (McKernan, 2005; McKeon, 2006). Furthermore, of the suite of human pressures on aquatic ecosystems discussed above, such as largescale water extraction, the construction of dams, groundwater pumping and changes in land use, most have served to exacerbate the effects of droughts when they do occur.

As with virtually all forms of management, strategies for dealing with drought can be broadly classified as either reactive or proactive. Proactive strategies include those implemented to reduce the impacts of droughts when they occur, and need not be triggered by the occurrence of drought. The construction of large dams provides a good example in terms of securing water resource needs for cities and agriculture. In contrast, reactive strategies are typically implemented only once a drought (or other disturbance event) occurs. The recent (2007) proposal to build a north-south pipeline connecting the city of Melbourne to the north flowing Goulburn River provides a clear example (Gardiner, 2007), and conflicts absolutely with existing government policy statements from as recently as April 2006 (Department of Sustainability and Environment, 2006).

A number of recent studies have suggested that reactive management strategies are often both more costly to implement and less successful than proactive strategies in mitigating the impacts of natural disturbances (e.g. Palmer et al., 2008), and there has thus been a gradual move towards such proactive strategies, particularly in dealing with floods. The Lower Goulburn Floodplain Rehabilitation project, requiring floodplain buybacks and levy removal, provides a good example from southern Australia (e.g. see PriceWaterhouseCoopers, 2001). For droughts, the case for proactive management may 
be even more compelling due to several unique aspects of this form of natural disturbance. First, in contrast to many other disturbances, which are often of relatively short-duration (e.g. days to months in the case of floods and fires), droughts may last from months to years. They also impact large areas of the landscape-much larger than most other disturbances. Finally, their duration, and hence also their severity, can be extremely difficult to predict, even once the onset of a drought has been recognised. Thus the impacts of drought and their ecological consequences can ramify through aquatic ecosystems long after the drought appears to have broken, or is declared to be over.

Presently, most of our responses to drought are reactive, such as the release of water flows to mitigate water quality problems and the housing of endangered species for later release. Whilst in many cases such reactive strategies may perform vital functions and save biota, they are in essence short-term responses to meet a crisis that has been made much worse by the existing degraded state of many aquatic ecosystems (Lake, 2005). We contend, first, that a substantial shift of emphasis is needed in the management of drought-from short-term crisis management to long-term proactive strategies that deal with the total problem of drought over large areas of the landscape together with strategies to mitigate other pressures such as future development and potential climate change (Lake \& Bond, 2007; Palmer et al., 2008). Second, cost/benefit analysis and decisions in sensitive matters such as water allocation and environmental flow delivery must be made within a much more rigorous framework that considers the present and projected future condition of ecosystems, together with uncertainty in future inflows to rivers, and hence the likelihood that drought conditions and their impacts will continue.

This perspective implies the design and implementation of long-term measures that protect catchments, their water resources and the associated aquatic ecosystems in the expectation that contemporary droughts as well as prolonged "megadroughts" will be the usual state of our environment rather than the exception. Rather than regarding droughts (and floods for that matter) as extreme events to be responded to when they occur, hydroclimatic variability should lie at the very core of our thinking as scientists and managers, and mould our approaches to managing and restoring ecosystems in a highly variable, drought-prone climate. Similar ideas have elsewhere been advocated for arid zone rivers (e.g. Boulton et al., 2000; Bunn et al., 2006), but not in specific relation to drought. Incorporating hydrological extremes into the management and restoration of landscapes and aquatic ecosystems will ensure that management strategies compromised by drought are identified, and, importantly, that management strategies designed to address drought impacts in the longer term are adequately implemented and maintained, even during non-drought periods.

\section{Principles for management before, during and after drought}

Underpinning drought management strategies should be the recognition that in their natural state, Australia's aquatic ecosystems and their biota have the capacity to recover from drought. As already discussed, historically, this capacity was ensured by the fact that even during severe droughts, some refuge habitats persisted, and the biota that survived in these areas were able to breed and repopulate other areas as drought broke, often, as is the case with La Nina events, with the onset of flooding (Lake, 2003).

However, as previously outlined, many of the human alterations to aquatic ecosystems and catchments, such as habitat alteration, water extraction, sedimentation, the construction of barriers, overfishing and the introduction of invasive species, have reduced this natural capacity to recover from drought. Again we would emphasise that a restored capacity to withstand natural disturbances is widely regarded as an important measure of restoration success (Bond \& Lake, 2005a; Jansson et al., 2005; Palmer et al., 2005). Thus, proactive strategies that address these problems, such as restoration in catchments and riverbank zones; provision and maintenance of refuge habits; some degree of flow in systems where much water is extracted; fish-passes to allow movement of fish around constructed barriers in the system, and the identification and active conservation of valuable ecosystems and particular biota, all contribute in minimising the impacts of drought. Already much investment is occurring in these forms of restoration across large areas of Australia, although arguably 
future efforts will need to be better coordinated and occur at larger scales in order to achieve ecological sustainability. In any case, the present drought has served to illustrate the fact that we are yet to adequately address many of these issues at the right time and at the appropriate spatial scale.

As well as these relatively generic strategies for restoring the resilience of aquatic ecosystems, there are several short-term strategies in which managers have begun to invest, including targeted environmental flows, the protection and creation of refuge habitat areas, and targeted species and population management. Below we provide some general comments on each of these strategies.

Refuge habitats

Refuge habitats exist across a broad spectrum of aquatic ecosystem types, and the types of refuge habitats that are important will depend on both the ecosystem type and the biota in question. Waterholes, floodplain lagoons and riverine pools are extremely valuable refugia (e.g. Arthington et al., 2005; Bond \& Cottingham, 2007), but are only some of the more prominent aquatic refugia utilised in riverine landscapes. Other types of refugia can be found in both temporary and permanent streams, such as logs, wet patches under banks, riffles, sub-surface stream sediments, yabby holes and littoral and riparian vegetation (Boulton, 2003). All of these remnant habitats can support obligate aquatic species or help to sustain moisture during dry spells and drought. These diverse refugia should be the highest priority for protection at all times, but especially during drought. For example, in upland streams that experience flow cessation, the fauna strongly dependent on flowing water, such as riffle-dwelling invertebrates (e.g. mussels (Golladay et al., 2004) and hydropsychid caddisflies), and some riffle-specialist fish species (Pusey et al., 2004), will decline in diversity and abundance. The spatial pattern and degree of drying is dependent on water volumes, channel morphology and hydrological connectivity. Here the provision of a low volume environmental flow may be an option below dams or weirs by allowing some percentage of inflowing water to be released downstream. Water quality issues may also need to be considered (e.g. thermal pollution and contaminants). Although shallow stream sections, such as riffles, will ultimately dry up during severe drought, deep pools, especially shaded ones, may persist throughout the drought, and need to be protected (e.g. fenced off) and not used to supply water for stock.

All types of stream refugia can be damaged by human activities with the effect that their capacity to sustain aquatic life during droughts may be severely diminished. Management actions should include protection of riparian vegetation, water quality (by limiting enriched runoff, or sedimentation of riffles and pools), restrictions on stock access and strong limits or prohibition on pool pumping and/or groundwater pumping near refugia.

Within particular geographic regions, protecting refuge habitats will need to:

1. Determine the physical characteristics of potential refuge habitats in streams.

2. Determine the location of refuges in the landscape.

3. Prioritise protection based on conservation principles (e.g. integrity, quality, connectivity).

4. Undertake proactive measures to protect and restore such refuges.

Temporary waterbodies, be they standing water or flowing water, will lose water and dry, or become a series of increasingly diminishing pools. Protective actions should include:

1. Maintaining riparian vegetation through the provision of targeted environmental flows and other measures (e.g. stock management).

2. No taking of fallen timbers (snags) as these help to maintain bank and habitat structure in the stream and also provide refugial habitats.

3. Protecting the stream from livestock and other sources of rural and human disturbance.

4. The prevention of activities that convert the dry streambed or dehydrated wetlands into arable land.

5. Maintenance of hydrologic connectivity of ephemeral streams and wetlands to more permanently flowing parts of a river system (i.e. no imposition of impassable barriers).

\section{Environmental flows}

River operational plans which seek to balance water allocation for extraction and environment water 
needs are in place for most Australian rivers (Arthington \& Pusey, 2003), but few of these include specific recommendations that deal with drought. As the value and scarcity of water has increased the necessity of environmental flow releases has become increasingly contentious, and to some degree this reflects differing philosophies about the sharing of water between consumptive users and the environment (Pigram, 2006). Casting these differences aside, there are specific ecosystems where mounting evidence suggests that the urgent delivery of environmental flows will be required to prevent the collapse of valued aquatic ecosystems and the species that comprise them.

One is the river red gum (Eucalyptus camaldulensis) forests along the lower Murray River. The river red gum is an iconic species of immense ecological significance in floodplain rivers, and a species already under enormous stress in some places. The poor condition of river red gums along the Murray River reflects long deprivation of natural river flows and the effects of increasing salinity (Maheshwari et al., 1995; Murray-Darling Basin Commission, 2003). Recent studies suggest that the continued failure to deliver environmental flows to river red gum forests in areas such as the Barmah-Millewa forest will cause irreversible loss of whole stands, as well as having likely impacts on many other plants and riverine fauna such as water birds (Kingsford, 2000; Kingsford \& Thomas, 2004). The most recent recommendations for the River Murray suggest a minimum flood magnitude of 4,000 GL at least every 5 years to restore and maintain the health of floodplain forests (Victorian Environment Assessment Council, 2007). To deliver such flow events will require that considerable water is held back between such events, even in dry years (Victorian Environment Assessment Council, 2007). It is therefore imperative that river managers integrate such multiyear planning into their drought response strategies, and that the need to store water for such events is more widely understood among politicians and the community at large. We have ample evidence in Australia of the ecological impacts and crushing loss of biodiversity when wetlands are deprived of intermittent floods (e.g. the Macquarie Marshes; Fazey et al., 2006).

Whilst careful planning should ensure some water remains in storage, in cases where storage volumes fall to critically low levels, such that the desired flows cannot be delivered, short-term mitigation strategies will be necessary. For example, in 2006 in the Loddon River in Victoria, it was recognised that, even with a reduction to the minimum baseflow released for environmental purposes, there was simply not enough water to sustain continuous releases well into the future. Instead, it was decided to introduce periods of zero flow interspersed with pulses of flow to maintain water quality in refuge pools. Coupled with water quality monitoring and complementary actions this scenario had the potential to save enough water over a 6-month summer period (October-March) to maintain the cycle for an additional 13 weeks (well into winter) without additional rainfall (Loddon River Environmental Flows Scientific Panel, 2006).

During drought there will be many circumstances like the Loddon River where the best environmental flow strategy is one that will protect refuge habitats and their biota (see refugia discussion above). In other cases it may be possible to call upon a "contingency flow" held in storage, and release periodic, but carefully timed flow pulses to simulate small floods. For example, a modest volume of flow at the right time of year might tip the scales in favour of beneficial ecological outcomes (e.g. seedling recruitment, fish spawning, water quality maintenance), sufficient to protect or sustain individual species or assemblages of species until the drought breaks. Again, the availability of such contingency flows will require proactive water management as well as some knowledge of the life history patterns and recruitment strategies of important species. In addition, we need to appreciate the role of flow regimes in supporting ecological functions such as nutrient spiralling, organic matter processing, food web dynamics, predator-prey dynamics and interactions between native and alien species (Bunn \& Arthington, 2002; Nilsson \& Svedmark, 2002; Pinay et al., 2002).

In systems with existing water management plans, various mechanisms are already in place to protect the environmental water share, such as limiting the volume of water pumped during flow releases, or the time of day of pumping, or setting 'cease to pump' levels (e.g. sustainable diversion limits in Victoria; Department of Natural Resources and Environment, 2002). Such rules should be reviewed and adjusted to 
take account of the critical water requirements of riverine biota during drought. Priority places (e.g. tributaries, reaches, runs, waterholes, isolated refugia) should be identified (see above). With sufficient knowledge of spatial arrangements it may be possible to modify the pattern of water abstraction so that particular streams or river reaches of high conservation value continue to receive some flow on a preferential basis. Such opportunities could arise by taking a more flexible approach to the approval, uptake and use of water licences. For example, it may be feasible to suspend particular water licences, or trade licences among properties, allowing some streams respite during drought, or even in the longer term. The contentious nature of environmental flow deliveries during drought and limited opportunities to procure water for the environment at such times only serve to highlight the importance of providing more adequate flows and more natural regimes when sufficient water is available.

Despite their appeal, prescriptive environmental flow rules are probably not going to be possible as a way of guiding water management during drought because each drought and its effects on river systems in their particular catchment contexts is likely to be highly individualistic. That said, in efforts to understand the impacts of drought and recovery from drought, the monitoring of ecological responses and benefits to managed environmental flows should be designed to encompass contrasting hydrological regimes and ecosystem types. This could yield valuable insight into how different types of river cope and recover from drought, and therefore could inform future efforts to manage environmental flows and river restoration strategies during drought.

\section{Species/population management and conservation}

Targeted species and population management during drought carries some unique challenges. Foremost amongst these is managing the loss of isolated local populations, particularly those of conservation significance. For rare taxa or those with few populations, further losses of genetic diversity caused by local population loss have the potential to greatly increase the risk of global extinctions. In such cases, and where less targeted interventions such as habitat and environmental flow management fail to provide sufficient protection, it may be necessary to implement targeted population management strategies such as the transfer of threatened populations into captivity for later reintroductions (e.g. Galaxias fuscus populations in Victoria), or the translocation of individuals from other areas once the drought has abated. Both of these strategies carry significant risk: as well as being costly, there is considerable potential to compromise natural population genetic structure and to transfer diseases among isolated populations (Daszak et al., 2000; Hughes et al., 2003; Krkosek et al., 2006). Where no alternatives exist, reintroductions are to be preferred over translocations as a means of protecting genetic diversity, but the risk of diseases being spread from culture facilities must also be considered (Cunningham, 1996). Identification of the situations where these sorts of interventions are needed may also highlight species/populations likely to fall victim to future droughts and ultimately to climate change.

Of related concern is the potential impact of interbasin water transfers on normally isolated catchments and populations. As well as moving water across the landscape such schemes can transfer native taxa, disrupting patterns of genetic isolation, and may also move exotic species and pathogens among catchments (e.g. Morison \& Anderson, 1991; Davies et al., 1992; Meador, 1992; Hughes et al., 2003). Various strategies, such as screens and water treatment have the capacity to manage these problems to some degree, although they are not always feasible and are frequently ineffective (Solomon, 1975).

\section{Key knowledge gaps}

At the outset, the key point should be made that in Australia, a drought-prone continent, there is no coordinated and well resourced research programme on droughts and their impacts; ecological, hydrological, social and economic. This gap needs to be addressed.

Research on the ecological effects of drought on aquatic systems has progressed substantially from case studies at different localities around the world. However, this comparative approach is generally limited by the absence of a clear index of drought severity, a lack of rigorous study designs, and the short duration of most studies, which are insufficient to monitor drought recovery (Lake et al., 2007). As 
supra-seasonal drought is an abnormal deficiency of water over time, it should be possible to develop a means of characterising this deviation from normal conditions that would allow comparison between different localities, much as for floods (e.g. see Poff, 1992).

There is a dearth of studies on the effects of drought on standing water bodies. Whilst the effects may be mild, it is important to document how water quality, the biota and ecological processes change with drought. Floodplains are a vital component of lowland rivers but our knowledge of the effects that droughts have on their aquatic biota and processes during extended dry periods and drought remains poor and fragmentary (Kingsford, 2006). With drought the movement of water, nutrients and trophic subsidies from the catchment and the riparian zone into streams becomes progressively weaker, if not ceased altogether. Drought combined with river regulation may severely damage the "flood pulse" boom of floodplain river systems (Bunn et al., 2006). Whilst we have some understanding of how the biota of running waters contend with drought at both the population and community levels, we have a poor understanding of how ecosystem processes, such as nutrient cycling or spiralling, and the nature of trophic interactions, change with drought, and whether permanent or lasting changes occur.

In an applied sense, research should pursue the question of what long-term proactive measures need to be progressively implemented to contend sustainably with drought and drying due to climate change. Proactive measures may involve strengthening hydrological and biological connectivity, both longitudinal and lateral, and protecting, if not augmenting, refugia. Implementation of these measures should be followed by appropriate monitoring so that the success or failure of each strategy can be judged, and improvements made over time.

\section{Conclusions}

The millennium drought, probably the worst since European settlement, has now exerted its influence across much of southern and eastern Australia for over half a decade. Although Australian river ecosystems are fully capable of surviving droughts when their surroundings are in a natural state, there is real scientific concern that humans have modified much of the Australian landscape to such an extent that survival and recovery after drought can no longer be taken for granted.

The natural capacity of many species and communities to recover from drought is now greatly impaired in Australia and in many drought-prone areas of the world. It is thus critical to recognise that the capacity of aquatic ecosystems to cope with drought has been lost or much reduced in many regions, but particularly those impacted by intensive land use, loss of riparian vegetation and water extraction.

Management responses to drought are also typically reactive and fail to consider uncertainties in the potential duration of drought events. We argue that our approaches to managing drought must be rethought. Given that floods and droughts are both common hydrological events and those which perhaps play the greatest role in shaping Australia's ecosystems, it is imperative that we better incorporate these events into both short and long-term water management strategies. Key steps will include rethinking the ways in which water is distributed between consumptive and environmental needs during drought and non-drought periods, together with improving the overall condition of catchments such that their natural capacity to withstand drought events is restored.

Acknowledgements This article emerged from an earlier initiative to summarise current knowledge of drought science and management in Australia, led by the eWater Cooperative Research Centre (CRC). The authors would like to acknowledge the many contributors to this earlier initiative, in particular Gary Jones, Ann Milligan, Jon Marshall, David Crook, Paul Reich and Margaret Brock. The authors also thank the eWater CRC and their respective institutions for academic and financial support, and two anonymous reviewers for comments and suggestions that much improved the final manuscript.

\section{References}

Adams, S. B. \& M. L. Warren, 2005. Recolonization by warmwater fishes and crayfishes after severe drought in upper coastal plain hill streams. Transactions of the American Fisheries Society 134: 1173-1192.

Andersen, C. M., L. Brannon, P. Gregory \& K. A. Sargent, 2004. Influence of wastewater-treatment effluent on concentrations and fluxes of solutes in the Bush River, South 
Carolina, during extreme drought conditions. Environmental Geosciences 11: 28-41.

Aravinthan, V., 2005. Reclaimed wastewater as a resource for sustainable water management. In Thorpe, D., U. Yadav, C. Snook \& G. Liang (eds), Southern Engineering Conference - Managing Resources for a Sustainable Future. Toowoomba, Australia.

Arthington, A. H., S. R. Balcombe, G. A. Wilson, M. C. Thoms \& J. Marshall, 2005. Spatial and temporal variation in fish-assemblage structure in isolated waterholes during the 2001 dry season of an arid-zone floodplain river, Cooper Creek, Australia. Marine and Freshwater Research 56: 25-35.

Arthington, A. H. \& B. J. Pusey, 2003. Flow restoration and protection in Australian rivers. River Research and Applications 19: 377-395.

Australian Bureau of Statistics, 2007. 1301.0 - Year book: Water use and irrigation. http://www.abs.gov.au/Ausstats/abs@. nsf/7d12b0f6763c78caca257061001cc588/9B24E6AB2227 EAEECA2572360006B929?opendocument. Accessed 28 October 2007.

Ball, J., L. Donnelley, P. Erlanger, R. Evans, A. Kollmorgen, B. Neal \& M. J. Shirley, 2001. Inland waters, Australia state of the environment report 2001 (Theme report). CSIRO Publishing on behalf of the Department of Environment and Heritage, Canberra, iii, $130 \mathrm{pp}$.

Bartley, R. \& I. Rutherfurd, 2005. Measuring the reach-scale geomorphic diversity of streams: Application to a stream disturbed by a sediment slug. River Research and Applications 21: 39-59.

Bond, N. R. \& P. Cottingham, 2007. Ecology and hydrology of temporary streams: Implications for sustainable water management. eWater CRC, Canberra.

Bond, N. R. \& P. S. Lake, 2005a. Disturbance regimes and stream restoration: The importance of restoring refugia. In Rutherfurd, I. D., I. Wisznewski, M. Askey-Doran \& R. Glazik (eds), 4th Australian Stream Management Conference: Linking Rivers to Landscapes, Launceston, Tasmania. Department of Primary Industries, Water and Environment, Hobart, Tasmania, 90-94.

Bond, N. R. \& P. S. Lake, 2005b. Ecological restoration and large-scale ecological disturbance: The effects of drought on the response by fish to a habitat restoration experiment. Restoration Ecology 13: 39-48.

Boulton, A. J., 2003. Parallels and contrasts in the effects of drought on stream macroinvertebrate assemblages. Freshwater Biology 48: 1173-1185.

Boulton, A. J. \& P. S. Lake, 1992. The ecology of two intermittent streams in Victoria, Australia II. Comparisons of faunal composition between habitats, rivers and years. Freshwater Biology 27: 99-121.

Boulton, A. J. \& P. S. Lake, 2008. Effects of drought on stream insects and its ecological consequences. In Lancaster, J. \& R. A. Briers (eds), Aquatic Insects: Challenges to Populations. CAB International, Wallingford, UK (in press).

Boulton, A. J., C. G. Peterson, N. B. Grimm \& S. G. Fisher, 1992. Stability of an aquatic macroinvertebrate community in a multiyear hydrologic disturbance regime. Ecology 73: 2192-2207.

Boulton, A. J., F. Sheldon, M. C. Thoms \& E. H. Stanley, 2000. Problems and constraints in managing rivers with variable flow regimes. In Boon, P. J., B. R. Davies \& G. E. Petts (eds), Global Perspectives on River Conservation: Science, Policy and Practice. John Wiley and Sons, London: 411-426.

Brazos River Authority, 2002. Brazos River Authority's Annual Water Quality Report. http://www.brazos.org/crpPDF/FY 02BasinHighlightsExecutive\%20Summary.pdf. Accessed 28 October 2007.

Briand, J., S. Jacquet, C. Bernard \& J. Humbert, 2003. Health hazards for terrestrial vertebrates from toxic cyanobacteria in surface water ecosystems. Journal of Veterinary Research 34: 361-377.

Brock, M. A., D. L. Nielsen, R. J. Shiel, J. D. Green \& J. D. Langley, 2003. Drought and aquatic community resilience: The role of eggs and seeds in sediments of temporary wetlands. Freshwater Biology 48: 1207-1218.

Bunn, S. E. \& A. H. Arthington, 2002. Basic principles and ecological consequences of altered flow regimes for aquatic biodiversity. Environmental Management 30: 492-507.

Bunn, S. E., M. C. Thoms, S. K. Hamilton \& S. J. Capon, 2006. Flow variability in dryland rivers: Boom, bust and the bits in between. River Research and Applications 22: 179-186.

Colley, J., 2004. Drought Preparedness Council Biennium Report 2003-2004. Governor's Division of Emergency Management, Austin, Texas.

Commonwealth Scientific and Industrial Research Organisation \& Australian Bureau of Meteorology, 2007. Climate Change in Australia: Technical Report 2007. CSIRO, Canberra, 148 pp.

Coughlan, M. J., 1985. Drought in Australia. In AATSE (ed.), Natural Disasters in Australia. Australian Academy of Technological Sciences and Engineering, Parkville, 127-149.

Cunningham, A. A., 1996. Disease risks of wildlife translocations. Conservation Biology 10: 349-353.

Dahm, C., M. A. Baker, D. I. Moore \& J. R. Thibault, 2003. Coupled biogeochemical and hydrological responses of streams and rivers to drought. Freshwater Biology 48: 1219-1231.

Daszak, P., A. A. Cunningham \& A. D. Hyatt, 2000. Emerging infectious diseases of wildlife - threats to biodiversity and human health. Science 287: 443-449.

Davies, A. W., 1978. Pollution problems arising from the 1975-76 drought. Proceedings of the Royal Society of London. Series A, Mathematical and Physical Sciences 363: 97-107.

Davies, B. R., M. C. Thoms \& M. Meador, 1992. An assessment of the ecological impacts of inter-basin water transfers, and their threats to river basin integrity and conservation. Aquatic Conservation: Marine and Freshwater Ecosystems 2: 325-349.

Department of Natural Resources and Environment, 2002. Sustainable Diversions Limit Project: Recommendations for Sustainable Diversion Limits over Winterfill Periods in Unregulated Victorian Catchments. DNRE, Melbourne.

Department of Sustainability and Environment, 2006. Draft Central Region Sustainable Water Strategy. Victorian Department of Sustainability and Environment, Melbourne. 
Douglas, M. R., P. C. Brunner \& M. E. Douglas, 2003. Drought in an evolutionary context: Molecular variability in Flannelmouth Sucker (Catostomus latipinnis) from the Colorado River Basin of western North America. Freshwater Biology 48: 1256-1275.

Druyan, L. M., 1996a. Arid climates. In Schneider, S. H. (ed.), Encyclopedia of Climate and Weather, Vol. 1. Oxford University Press, New York, USA: 48-50.

Druyan, L. M., 1996b. Drought. In Schneider, S. H. (ed.), Encyclopedia of Climate and Weather, Vol. 1. Oxford University Press, New York, USA: 256-259.

Elliott, J. M., 2006. Periodic habitat loss alters the competitive coexistence between brown trout and bullheads in a small stream over 34 years. Journal of Animal Ecology 75: 54-63.

Fazey, I., K. Proust, B. Newell, B. Johnson \& J. A. Fazey, 2006. Eliciting the implicit knowledge and perceptions of on-ground conservation managers of the Macquarie Marshes. Ecology and Society 11: 25.

Furey, P. C., R. N. Nordin \& A. Mazumder, 2006. Littoral benthic macroinvertebrates under contrasting drawdown in a reservoir and a natural lake. Journal of the North American Benthological Society 25: 19-31.

Gardiner, A., 2007. Protesters Pipe in Water Anger. Sunday Herald Sun, Melbourne.

Gehrke, P. C., M. B. Revell \& A. W. Philbey, 1993. Effects of river red gum, Eucalyptus camaldulensis, litter on golden perch, Macquaria ambigua. Journal of Fish Biology 43: 265-279.

Gibbs, W. J. \& J. V. Maher, 1967. Rainfall Deciles as Drought Indicators. Bureau of Meteorology, Melbourne, Australia.

Golladay, S. W., P. Gagnon, M. Kearns, J. M. Battle \& D. W. Hicks, 2004. Response of freshwater mussel assemblages (Bivalvia: Unionidae) to a record drought in the Gulf Coastal Plain of southwestern Georgia. Journal of the North American Benthological Society 23: 494-506.

Graham, R. \& J. H. Harris, 2005. Floodplain Inundation and Fish Dynamics in the Murray-Darling Basin. Current Concepts and Future Research: A Scoping Study. Cooperative Research for Freshwater Ecology, Canberra, Australian Capital Territory, $52 \mathrm{pp}$.

Ha, K., E.-A. Cho, H.-W. Kim \& G.-J. Joo, 1999. Microcystis bloom formation in the lower Nakdong River, South Korea: Importance of hydrodynamics and nutrient loading. Marine and Freshwater Research 50: 89-94.

Hughes, J., K. Goudkamp, D. Hurwood, M. Hancock \& S. Bunn, 2003. Translocation causes extinction of a local population of the freshwater shrimp Paratya australiensis. Conservation Biology 17: 1007-1012.

Humphries, P. \& D. S. Baldwin, 2003. Drought and aquatic ecosystems: An introduction. Freshwater Biology 48: 1141-1146.

Jansson, R., H. Backx, A. J. Boulton, M. Dixon, D. Dudgeon, F. M. R. Hughes, K. Nakamura, E. H. Stanley \& K. Tockner, 2005. Stating mechanisms and refining criteria for ecologically successful river restoration: A comment on Palmer et al. (2005). Journal of Applied Ecology 42: 218-222.

Jenkins, K. M. \& A. J. Boulton, 2007. Detecting impacts and setting restoration targets in arid-zone rivers: Aquatic micro-invertebrate responses to reduced floodplain inundation. Journal of Applied Ecology 44: 823-832.
Keyantash, J. \& J. A. Dracup, 2002. The quantification of drought: An evaluation of drought indices. Bulletin of the American Meteorological Society 83: 1167-1180.

Kingsford, R. T., 2000. Ecological impacts of dams, water diversions and river management on floodplain wetlands in Australia. Austral Ecology 25: 109-127.

Kingsford, R. T., 2006. Ecology of Desert Rivers. Cambridge University Press, Cambridge.

Kingsford, R. T. \& F. I. Norman, 2002. Australian waterbirds products of the continent's ecology. Emu 102: 47-69.

Kingsford, R. T. \& R. F. Thomas, 2004. Destruction of wetlands and waterbird populations by dams and irrigation on the Murrumbidgee River in arid Australia. Environmental Management 34: 383-396.

Krkosek, M., M. A. Lewis, A. Morton, L. N. Frazer \& J. P. Volpe, 2006. Epizootics of wild fish induced by farm fish. Proceedings of the National Academy of Sciences 103: 15506-15510.

Kushlan, J. A., 1976. Wading bird predation in a seasonally fluctuating pond. The Auk 93: 464-476.

Lake, P. S., 2003. Ecological effects of perturbation by drought in flowing waters. Freshwater Biology 48: 1161-1172.

Lake, P. S., 2005. Perturbation, restoration and seeking ecological sustainability in Australian flowing waters. Hydrobiologia 552: 109-120.

Lake, P. S., 2006. Drought, the “Creeping Disaster". Effects on Aquatic Ecosystems. Land and Water Australia, Canberra, $61 \mathrm{pp}$.

Lake, P. S. \& N. R. Bond, 2007. Australian futures: Aquatic ecosystems and human water usage. Futures 39: 288-305.

Lake, P. S., P. Reich \& N. R. Bond, 2007. Drought in Freshwater Ecosystems: An Appraisal of Progress. International Society of Limnology (SIL) Annual Conference Proceedings, Montreal, Canada.

Lind, P. R., B. J. Robson \& B. D. Mitchell, 2006. The influence of reduced flow during a drought on patterns of variation in macroinvertebrate assemblages across a spatial hierarchy in two lowland rivers. Freshwater Biology 51: 2282-2295.

Loddon River Environmental Flows Scientific Panel, 2006. Loddon-Campaspe drought response options - environmental flow management. Loddon River Environmental Flows Scientific Panel report to the North Central Catchment Management Authority, Bendigo.

Magalhaes, M. F., P. Beja, I. J. Schlosser \& M. J. CollaresPereira, 2007. Effects of multi-year droughts on fish assemblages of seasonally drying Mediterranean streams. Freshwater Biology 52: 1494-1510.

Magoulick, D. D. \& R. M. Kobza, 2003. The role of refugia for fishes during drought: A review and synthesis. Freshwater Biology 48: 1186-1198.

Maheshwari, B. L., K. F. Walker \& T. A. McMahon, 1995. Effects of regulation on the flow regime of the river Murray, Australia. Regulated Rivers: Research \& Management 10: 15-38.

Matthews, W. J., 1998. Patterns in Freshwater Fish Ecology. Chapman \& Hall, New York.

Matthews, W. J. \& E. Marsh-Matthews, 2003. Effects of drought on fish across axes of space, time and ecological complexity. Freshwater Biology 48: 1232-1253.

McKeon, G., 2006. Living in a Variable Climate. Article Prepared for the 2006 Australia State of the Environment 
Committee, Department of environment and Heritage, Canberra.

McKernan, M., 2005. Drought. The Red Marauder. Allen \& Unwin, Crows Nest, NSW, Australia.

McMahon, T. A. \& B. L. Finlayson, 2003. Droughts and antidroughts: The low flow hydrology of Australian rivers. Freshwater Biology 48: 1147-1160.

McMaster, D. M. \& N. R. Bond, 2008. Effects of DOC and DO on Fish Assemblages in Drying Stream Pools. Marine and Freshwater Research (in press).

McMurray, D., 2006. Impact of Farm Dams on Streamflow in the Tod River Catchment, Eyre Peninsula, South Australia. Department of Water, Land and Biodiversity Conservation, Adelaide.

Meador, M. R., 1992. Inter-basin water transfer: Ecological concerns. Fisheries 17: 17-22.

Medeiros, E. S. F. \& L. Maltchik, 1999. The effects of hydrological disturbance on the intensity of infestation of Lernaea cyprinacea in an intermittent stream fish community. Journal of Arid Environments 43: 351-356.

Morison, A. K. \& J. R. Anderson, 1991. Galaxias brevipinnis Günther (Pisces: Galaxiidae) in north-eastern Victoria: First records for the Murray-Darling drainage basin. Proceedings of the Royal Society of Victoria 103: 17-28.

Murphy, B. F. \& B. Timbal, 2007. A review of recent climate variability and climate change in southeastern Australia. International Journal of Climatology. doi:10.1002/ joc. 1627.

Murray-Darling Basin Commission, 2003. Preliminary Investigations into Observed River Red Gum Decline Along the River Murray Below Euston. Murray-Darling Basin Commission, Canberra.

Murray-Darling Basin Commission, 2007. River Murray system - Drought Update No. 7 April 2007. Murray-Darling Basin Commission, Canberra.

National Land and Water Resources Audit, 2002. Australian Catchment, River and Estuary Assessment 2002. National Land and Water Resources Audit, Canberra, ACT, 193-386.

Nilsson, C. \& M. Svedmark, 2002. Basic principles and ecological consequences of changing water regimes: Riparian plant communities. Environmental Management 30: 468-480.

Palmer, M., E. Bernhardt, J. D. Allan, P. S. Lake, G. Alexander, S. Brooks, J. Carr, S. Clayton, C. Dahm, J. Follstad Shah, D. L. Galat, S. Gloss, P. Goodwin, D. H. Hart, B. Hassett, R. Jenkinson, G. M. Kondolf, R. Lave, J. L. Meyer, T. K. O'Donnell, L. Pagano, P. Srivastava \& E. Sudduth, 2005. Standards for ecologically successful river restoration. Journal of Applied Ecology 42: 208-217.

Palmer, M. A., C. Reidy, C. Nilsson, M. Florke, J. Alcamo, P. S. Lake \& N. R. Bond, 2008. Climate change and the world's river basins: Anticipating response options. Frontiers in Ecology and the Environment 6. doi:10.1890/ 060148.

Pigram, J. J., 2006. Australia's Water Resources. CSIRO Publishing, Melbourne, 226 pp.

Pinay, G., J. C. Clément \& R. J. Naiman, 2002. Basic principles and ecological consequences of changing water regimes on nitrogen cycling in fluvial systems. Environmental Management 30: 481-491.
Poff, N. L., 1992. Why disturbance can be predictable: A perspective on the definition of disturbance in streams. Journal of the North American Benthological Society 11: 86-92.

Poiani, A., 2007. Effects of floods on distribution and reproduction of aquatic birds. In Poiani, A. (ed.), Advances in Ecological Research. Elsevier Academic Press, San Diego.

PriceWaterhouseCoopers, 2001. Lower Goulburn Floodplain Rehabilitation Scheme: Business Plan Summary. PriceWaterhouseCoopers, Melbourne.

Pusey, B. J. \& A. H. Arthington, 2003. Importance of the riparian zone to the conservation and management of freshwater fish: A review. Marine and Freshwater Research 54: 1-16.

Pusey, B., M. Kennard \& A. Arthington, 2004. Freshwater Fishes of North-eastern Australia. CSIRO Publishing, Collingwood, VIC, xiv, $684 \mathrm{pp}$.

Schiewer, U., 1998. 30 years' eutrophication in shallow brackish waters - lessons to be learned. Hydrobiologia 363: 73-79.

Solomon, D., 1975. Water transfers and coarse fisheries. In Proceedings of the 7th British Coarse Fish Conference, Liverpool, England, 14-20.

Stanley, E., S. G. Fisher \& J. B. Jones, 2004. The effects of water loss on primary production: A landscape scale model. Aquatic Sciences 66: 130-138.

Tramer, E., 1977. Catastrophic mortality of stream fishes trapped in shrinking pools. American Midland Naturalist 97: 469-478.

Unmack, P. J., 2001. Fish persistence and fluvial geomorphology in central Australia. Journal of Arid Environments 49: 653-669.

Van Dijk, A. I. J. M., R. Evans, P. Hairsine, S. Khan, R. Nathan, Z. Paydar, N. Viney \& L. Zhang, 2006. Risks to the Shared Water Resources of the Murray-Darling Basin. Murray-Darling Basin Commission, Canberra, 49 pp.

Van Lanen, H. A. J. \& E. Peters, 2000. Definition, effects and assessment of groundwater droughts. In Vogt, J. V. \& F. Somma (eds), Drought and Drought Management in Europe. Kluwer, Dordrecht: 49-61.

Velasco, J. \& A. Millan, 1998. Insect dispersal in a drying desert stream: Effects of temperature and water loss. Southwestern Naturalist 43: 80-87.

Victorian Environment Assessment Council, 2006. River Red Gum Forests Investigation: Discussion Paper. Victorian Environment Assessment Council, Melbourne.

Victorian Environment Assessment Council, 2007. River Red Gum Forests Investigation: Draft Proposals for Public Comment. Victorian Environment Assessment Council, Melbourne.

Vidal, J., 2006. Algae Choking Drought-hit Ponds and Streams. The Guardian, London.

Walsh, C. J., A. H. Roy, J. W. Feminella, P. D. Cottingham, P. M. Groffman \& R. P. Morgan, 2005. The urban stream syndrome: Current knowledge and the search for a cure. Journal of the North American Benthological Society 24: 706-723.

Wilhite, D. A., 2000. Drought as a natural hazard: Concepts and definitions. In Whlhite, D. A. (ed.), Drought: A Global Assessment, Vol. 1. Routledge, London: 3-18. 